ISSN: 2581-8341

Volume 04 Issue 12 December 2021

DOI: 10.47191/ijcsrr/V4-i12-17, Impact Factor: 5.825

IJCSRR@ 2021

WwW.ijcsrr.org

\title{
Creative Destruction - An Inevitable Reality for the Financial Services Sector in Zambia?
}

\author{
Billy Kaombe $^{1}$, Francis Mukosa ${ }^{2}$, Dr. Windu Matoka ${ }^{3}$, Rabbie Mukuma ${ }^{4}$ \\ 1,2, ${ }^{4}$ ZCAS Professional Studies, Lusaka, Zambia \\ ${ }^{3}$ ZCAS University School of Business
}

\begin{abstract}
The financial services sector in Zambia has become increasingly exposed to the ever-growing challenges posed by mobile network operators (MNOs). The introduction of mobile money by MNOs has witnessed increased usage of mobile money services. During the same period, there has been a noticeable decline in the usage of digital banking services. The research study therefore sought to establish whether there was a correlation between increased usage of mobile money services and usage of digital banking services in Zambia. The study was quantitative in nature and was based on secondary data sources. Data from 19 of the 21 digital financial services providers in Zambia were analysed using times series trend analysis and simple linear regression analysis. In order to establish whether a correlation existed between increased usage of mobile money services and usage of digital banking services in Zambia, a t- test was conducted. This acted as a guide to the decision as to whether or not to accept or reject the null hypothesis. The study failed to reject the null hypothesis and therefore concluded that no correlation existed between increased usage of mobile money services and usage of digital banking services. However, the study expounded the research results in terms of Schumpeter, Christensen and Foster's ideas on disruptive innovation.
\end{abstract}

KEYWORDS: Creative Destruction; Disruptive Innovation; Digital Financial Services; Digital Banking Services; Financial Services Sector; Innovation; Mobile Network Operators; Mobile Money Services

\section{INTRODUCTION}

The "good old days" when commercial banks dominated the financial services sector in Zambia are clearly over. The financial services sector has become increasingly exposed to the ever-growing challenges posed by non-traditional players, such as mobile network operators (MNOs), who employ innovation and technology to create customer-orientated financial services solutions (PwC Zambia, 2019). A key innovation of MNOs has been the provision of digital financial services using mobile digital platforms. Zambia has recorded an increase in the usage of mobile money services by adults from 14.0 percent in 2015 to 58.5 percent in 2020 (FinScope, 2020). During the same period, Zambia has experienced a noticeable decline in adult usage of formal banking services from 24.8 percent in 2015 to 20.7 percent in 2020 (FinScope, 2020). The financial services sector appears to be experiencing a phenomenon described by Schumpeter (1942) as "creative destruction" - a process that involves "a deliberate dismantling of established practices and processes so as to pave way for innovations." (Hayter, 2017; Nicholas, 2020) Few companies can claim to be immune from the forces of creative destruction (Innosight, 2012). Despite operating outside the formal banking system, the MNOs have made considerable inroads in the financial services sector through provision of mobile money services (Chileshe, 2019; Suri et al., 2021). Mobile phone markets and networks, and the accompanying digitalization have presented new business opportunities to MNOs. The MNOs have added massive value for, and offer beneficial services to customers in the financial services sector. Previously inhibited by inadequate banking infrastructure and high transaction costs, MNOs are currently offering much more accessible and affordable financial services via mobile money agents (FinScope, 2020). MNOs have progressively invested in agent and distributor networks in order to increase their market reach. Consequently, the market penetration rate of mobile money agents is said to have become seven (7) times more than that of automated teller machines (ATMs) and 20 times more than that of branch networks of banks (United Nations Capital Development Fund, 2020). As such, mobile money agents have had a transformative impact on financial inclusion, particularly in remote areas (Chileshe, 2019) Mobile money agents offer customers a cost advantage owing to the considerable reduction in transaction costs, as well as enhanced convenience, security and speed. 


\section{International Journal of Current Science Research and Review}

ISSN: 2581-8341

Volume 04 Issue 12 December 2021

DOI: 10.47191/ijesrr/V4-i12-17, Impact Factor: 5.825

IJCSRR@ 2021

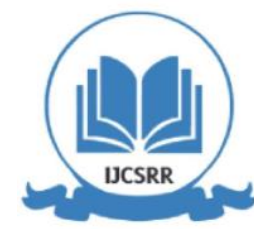

Www.ijcsrr.org

\section{Background}

Zambia is a developing nation that is faced with a huge demographic shift in terms of the composition of its population. The country boasts of one of the world's youngest population by median age. Zambia's population is estimated to stand at about 17.9 million and continues to grow steadily at a rate of 2.8 percent per annum (World Bank, 2021). This trend in growth is expected to continue as the youth population enters reproductive age. However, the growth in the population has not been accompanied by a growth in the country's economy which has remained subdued since 2015 (FinScope, 2020). The prolonged stall in Zambia's economic growth is expected to be further compounded by the Covid-19 pandemic which has exacerbated Zambia's macroeconomic vulnerabilities. This state of affairs presents challenges for households as it speaks to diminished income-generating opportunities. It is during such times as these that the requirement for higher levels of financial inclusion becomes imperative (Chileshe, 2019). Financial inclusion has been defined by Zambia's National Financial Inclusion Strategy (2017 - 2022) as being "access to and informed usage of a broad range of quality and affordable savings, credit, payment, insurance, and investment products and services that meet the needs of individuals and businesses." (de Bruijn, Butter, \& Fall, 2017) An enhanced access to financial products and services through the various digital platforms, including mobile money services is "a first step towards broader financial inclusion, since it permits people to save money, send and receive payments.” (de Bruijn, Butter, \& Fall, 2017)

\section{Mobile money services in Zambia}

Zambia has made significant progress in the area of financial inclusion despite the prevailing economic challenges. Formal financial inclusion in Zambia rose to 61.3 percent in 2020 from 38.2 percent in 2015 (FinScope, 2020). The growth in financial inclusion can partly be attributed to increased usage of mobile money services that rose to 58.5 percent in 2020 from 14.0 percent in 2015 (FinScope, 2020). Mobile money services in Zambia are provided primarily by three MNOs namely: MTN, Airtel and Zamtel. Airtel and MTN began offering mobile money services in 2011 and 2012, respectively (de Bruijn, Butter, \& Fall, 2017). Zamtel began offering mobile money services much later. Other than the banking and non - deposit taking financial institutions, MNOs face competition from several other money transfer systems that are popular amongst the Zambia's population. These include Swift Cash (a money transfer service provided by the Zambia Postal Services Corporation), Shoprite (a major South African supermarket chain that offers national money transfer and payment services to its customers) Western Union and MoneyGram (de Bruijn, Butter, \& Fall, 2017). Zoona also continue to provide money transfer options to Zambians.

Mobile money represents a payment option that sits on a consumers' mobile phone and operates through a series of menu options (de Bruijn, Butter, \& Fall, 2017; Chileshe, 2019). Mobile money systems lie outside the domain of formal banking (Suri et al., 2021). Using a mobile phone, consumers are able to perform a plethora of financial transactions that include "person-to-person (P2P) payments, paying utility bills, storing and holding money, person-to-business (P2B) payments, and receiving payments from businesses (such as salaries)" (Suri et al. , 2021; UNCDF, 2020). Mobile money also facilitates for bulk payments such as salaries to employees and casual laborers. (de Bruijn, Butter, \& Fall, 2017) To achieve interoperability and integration, banks in partnership with MNOs have begun to build digital bank accounts and digital lending systems that operate over the rails of mobile money (de Bruijn, Butter, \& Fall, 2017; Suri et al., 2021). These accounts operate by facilitating the transfer of money between a mobile money e-wallet and the digital bank account (Chileshe, 2019).

MNOs require customers to have an account in order to make transfers or make payment (de Bruijn, Butter, \& Fall, 2017). The procedures for opening and operating a mobile money account are straightforward compared to a bank account. The initial step requires the consumer to register the mobile money account with their preferred MNO through a mobile money agent. To complete the registration process, the consumer must provide the necessary information in line with the Know Your Customer (KYC) regulations (Suri et al. , 2021). To initiate any payments from the account, a consumer is required to make a cash deposit (just like in a bank account) at any mobile money agent in the country (de Bruijn, Butter, \& Fall, 2017). The process does not involve any kind of paper work. To transfer money or to make a payment from the mobile network, the consumer must log-in to their mobile money account using a secret user-ID and select the required action from the menu options. Cash withdrawals can also be done at any mobile money agent under the same MNO. Mobile money transactions (with the exception of cash deposits) attract transaction fees (Chileshe, 2019). Consumers receive alerts in real time on their mobile phone for any transaction made on their account. This serves as an added security feature for mobile money services. 


\section{International Journal of Current Science Research and Review}

ISSN: 2581-8341

Volume 04 Issue 12 December 2021

DOI: 10.47191/ijesrr/V4-i12-17, Impact Factor: 5.825

IJCSRR@ 2021

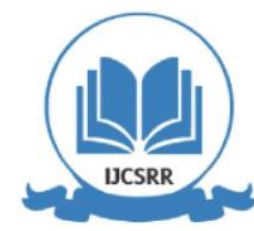

Www.ijcsrr.org

Though the consumer side of mobile money bear similarities to operating a bank account, the back-end of the mobile money system and the way it operates are quite different (Suri et al., 2021). Money sitting in a mobile money account does not represent actual cash. Rather, it is called e-money (or electronic money) and "trades one-for-one with cash, less any transaction costs" (Suri et al., 2021). When a consumer makes a cash deposit in their mobile money account, they are in fact buying an equivalent amount in emoney from a mobile money agent. Mobile money agents have an obligation legally to hold a float of e-money to facilitate transactions with their customers. It follows, therefore that cash withdrawals represent an exchange of e-money for an equivalent amount of cash from a mobile money agent, less transaction costs (Chileshe, 2019).

\section{Drivers of mobile money services in Zambia}

According to FinScope survey of 2020, the use of mobile money services by adults increased from 14.0 percent in 2015 to 58.5 percent in 2020. The key driver of mobile money services in Zambia appears to be the growing use of digital technologies amongst the Zambian population (Chileshe, 2019). The Covid - 19 pandemic has also contributed to the adoption of digital services across many sectors, including the financial services sector in sub-Saharan Africa (UNCDF,2020). Other drivers of mobile money services are directly linked to challenges encountered by both current and potential customers in developing economies such as Zambia in accessing and using commercial bank products or services (UNCDF,2020). These challenges include the following (FinScope, 2020; PwC Zambia, 2019):

a) Insufficient money: Retail customers lack sufficient money to enable them maintain bank accounts. The lack of money can be attributed to high unemployment levels and the economic challenges that Zambia is facing (FinScope, 2020). Therefore, mobile money accounts offer an affordable alternative to maintaining bank accounts.

b) Distance to banks: The problem of distance to banks and inadequate banking infrastructure has made mobile money services an attractive alternative to many people (UNCDF, 2020). Insufficient banking infrastructure has added to the high cost of transportation in accessing banking services. Contrary to this, MNOs have invested in an extensive network of mobile money agents thereby increasing their reach in the financial services market. The reach of a mobile money agent is said to be seven (7) times that of automated teller machines (ATMs) and 20 times that of bank branches (UNCDF, 2020).

c) High minimum balances: Most commercial banks require customers to maintain a minimum balance in their account, which a majority of people consider to be high. In contrast, there is no requirement of maintaining minimum balances in mobile money accounts.

d) High bank service charges: Transaction fees, including maintenance fees, on bank accounts are comparably higher than the fees charged on mobile money accounts for similar transactions. Mobile money account does not attract maintenance fees. The only requirement is for someone to be an active subscriber on a particular network.

e) No demonstrable benefits: Most commercial banks that offer retail commercial banking services target customers in formal employment and offer their customers salary bank accounts. Beyond that, therefore, a majority of bank consumers rarely see any demonstrable benefits of maintaining bank accounts. MNOs have also begun to facilitate bulk payments such as salaries to employees and casual labourers (de Bruijn, Butter, \& Fall, 2017)

\section{Research gap and statement of problem}

Many studies have been conducted in developing countries on the financial services sector with the main focus being on challenges facing financial institutions, especially in the area of financial inclusion (PwC Zambia, 2019; Chileshe, 2019; UNCDF, 2020). Similarly, many other studies have been conducted on mobile money services (Suri, 2021) and their contribution to the growth of the financial services sector (FinScope, 2020). Studies on the state of the financial services industry in Zambia has revealed that enhanced access to financial products and services can be attained through the various digital platforms, including mobile money services (de Bruijn, Butter, \& Fall, 2017). It therefore follows that MNOs, just like commercial banks, can make a positive contribution to the growth of financial inclusion in Zambia (FinScope, 2020). Evidently, there has been an increase in usage of mobile money services among the adult population in Zambia (FinScope, 2020). During the same period, the financial services sector has witnessed a noticeable decline in the usage of digital banking services. What is not evident is whether there is a correlation between increased usage of mobile money services and the decline in the usage of digital banking services since no specific studies have been conducted to establish whether such a relationship exists. The researchers therefore considered it appropriate to conduct a study aimed at establishing whether or not a correlation existed between increased usage of mobile money services and usage of digital banking 


\section{International Journal of Current Science Research and Review}

ISSN: 2581-8341

Volume 04 Issue 12 December 2021

DOI: 10.47191/ijcsrr/V4-i12-17, Impact Factor: 5.825

IJCSRR@ 2021

WwW.ijcsrr.org

services in Zambia. If such a relationship was found to exist, the study intended to examine whether the financial services sector in Zambia was on the trajectory of succumbing to "the siren call of creative destruction." (Innosight, 2012)

\section{Research objective and question}

Following from the research gap and the statement of problem, the objective of this research study was to evaluate the impact of increased usage of mobile money services on the usage of digital banking services in Zambia. As a guide to this research, the study sought to address the following research question: "What was the impact of increased usage of mobile money services on usage of digital banking services in Zambia?"

\section{Research propositions}

Following from the research objective and research question, the study hypothesized as follows:

$\mathrm{H}_{\mathrm{o}}: \mathrm{p}=0$ (that is, there was no correlation between the increased usage of mobile money services and the usage of digital banking services in Zambia)

$\mathrm{H}_{1}: \mathrm{p}<0$ (that is, an inverse correlation existed between the increased usage of mobile money services and usage of digital banking services in Zambia).

\section{Significance of the study}

The researchers considered this study to be important as the research findings would assist banks and other financial institutions in the financial services sector to decide as to whether to simply continue on their current course rather than managing for long-term evolution of their product lines to maintain pace with the overall changes in the financial services sector (Innosight, 2012).

\section{Operational definitions of terms}

- Digital financial services (DFS): DFS is general term used to describe a suite of financial services accessed and provided through digital channels (de Bruijn, Butter, \& Fall, 2017). Digital channels include ATMs, agents, point-of-sale terminals, mobile phones (UNCDF, 2020). According to the UNCDF (2020), this includes "e-money and bank accounts held at financial institutions (banks, microfinance institutions) and non-financial providers (mobile network operators (MNOs), financial technology companies, cooperatives and other third-party providers and includes all payment instruments."

- Digital banking services: Digital banking services include all financial services accessed through digital channels operated by a bank, such ATMs and point-of-sale terminals.

- Mobile money: Mobile money is described as "electronic money transferred via a mobile network operator (MNO) and SIMenabled devices". (de Bruijn, Butter, \& Fall, 2017) For the purposes of this research, mobile money shall be used to describe electronic money transferred via MNO. A mobile money operator (MNO) is "a company that has a government-issued licence to provide telecommunication services through mobile devices" (UNCDF, 2020).

\section{LITERATURE REVIEW}

\section{Introduction}

This section reviews influential literature on the concept of creative destruction. A number of writers are behind the development of the concept of creative destruction. Notable amongst these writers that merit consideration here, include Joseph A. Schumpeter (1934; 1939; 1942), Richard Foster (1986) and Clayton Christensen (1997; 2018). The section also addresses the advantages and disadvantages of creative destruction, and provides some global perspectives on the subject.

\section{Schumpeterian Theory on Innovation}

Schumpeter (1942) played an influential role in shaping initial ideas on disruptive innovation. Schumpeter, whose work was greatly influenced by his critical review on equilibrium theory, intended to study the dynamics behind the empirically observable economic change. (Grebel, Pyka, \& Hanusch, 2001). Schumpeter introduced the concept of "creative destruction", which, according to him, results in "industrial mutation", which could be regarded as innovation (Hayter, 2017). According to Schumpeter (1942), creative destruction "is the destruction of older, dominant businesses and the renewal of industries" (Schumpeter, 1942). Innovation was defined for all practical purposes "as the successful introduction of new products and processes" (Stolper, 1994; Hagedoorn,1996). Schumpeter's theory of innovation concentrated on the dynamics of business rather than market equilibrium. (Hagedoorn J. , 1996) Schumpeter's ideas on innovation integrate the concept of entrepreneurship and changes in technology into the business model of 


\section{International Journal of Current Science Research and Review}

ISSN: 2581-8341

Volume 04 Issue 12 December 2021

DOI: 10.47191/ijesrr/V4-i12-17, Impact Factor: 5.825

IJCSRR@ 2021

www.ijcsrr.org

innovation, arguing that their introduction creates an imbalance in markets (Grebel, Pyka, \& Hanusch, 2001). Schumpeter (1942) posits that "businesses that fail to take advantage of available innovations are destroyed by the creative disruption of the new businesses." The imbalance caused by the introduction of innovation creates opportunities for new ideas and processes, which encourages more innovation (Hagedoorn J. , 1996).

\section{Richard N. Foster}

Richard N. Foster (1986), in his book "Innovation: The Attackers Advantage" presented several ideas on creative destruction. The central idea presented in his book was that "attackers" endeavor to make money by changing the order of things and "defenders" safeguard their existing cash flows (Anthony, Viguerie, \& Schwartz, 2018). To expound his ideas, Foster (1986) used the S-curves to depict the technology limits. For all practical purposes, "technology" means the manner in which something or anything is performed. Foster (1986) posits that technological progress is slow at the start, and then progress accelerates rapidly and then begins to slow, as the technology reaches maturity. Beyond a certain point, no amount of additional investment in a technology will significantly improve performance (Anthony et al., 2018). At this point, another technology emerges to take its place. New entrants generate payoffs by exploring new innovations whereas incumbents focus on innovations that protect their existing cash flows (Foster \&. Kaplan, 2001). Eventually, the paths of these technologies intersect, and through the process of disruption from below, incumbents often lose control of the market. Three concepts underlie Foster's (1986) approach: The S- curve depicting the basic pattern of technological change; technological discontinuities that occur as a particular technology reaches maturity and another appears to supplant it; and the inherent economic advantage that attackers enjoy (Foster \& Kaplan, 2001).

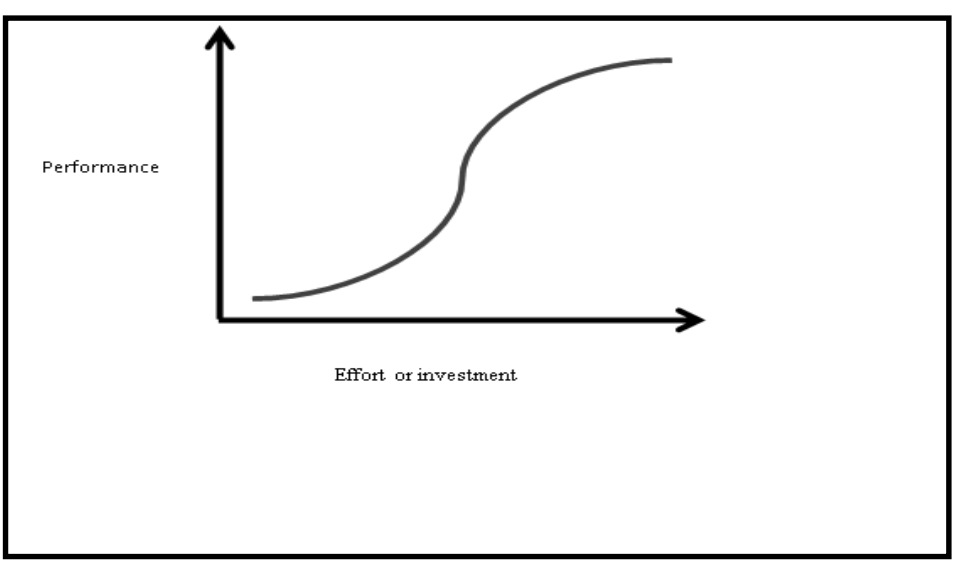

\section{Clayton Christensen - Theory of Disruptive Innovation}

The theory of disruptive innovation is attributed to Clayton Christensen (Nicholas, 2020). The key argument behind the theory is that disruptive technologies can precipitate the failure of well-established firms (Christensen, 1997). The theory expounds the phenomenon by which an entrant in the market is able to successfully challenge incumbent businesses (Nord, 1987; Urabe, 1988 and West, 1990). New entrants in markets can be distinguished by the type of innovation they represent, which can be either "sustaining" or "disruptive". (Christensen, Raynor, \& McDonald, 2018)

Sustaining innovations can be radical breakthroughs or incremental improvements, but they all make it possible for firms to sell more products to their most lucrative customers (Christensen, Raynor, \& McDonald, 2018). Sustaining innovations can be introduced by new entrants or incumbent firms. On the other hand, disruptive innovations can be "low-cost" or "new market", and are generally considered to be simpler, affordable and more convenient than products offered by incumbent firms (Christensen et al., 2018). As the incumbent firms concentrate on product improvements for their most lucrative customers, they tend to exceed the performance requirements of certain segments of the market and neglect the needs of others (Christensen C. M., 1997). Entrants that prove to be disruptive succeed by going after those segments that have been overlooked. They gain a foothold in those segments by delivering more suitable products, often at a lower price (Lin, 2007). Incumbents tend not to react forcefully to the entrant's actions because the entrants concentrate on overlooked segments rather than on the incumbents' core markets. The dilemma that faces the incumbent firm is that even if it observes changes to products and industry dynamics, there is not much that managers can do about it (Christensen, 1997). Eventually the entrants move upmarket, delivering the performance demanded by the incumbents' core market, while 


\section{International Journal of Current Science Research and Review}

ISSN: 2581-8341

Volume 04 Issue 12 December 2021

DOI: 10.47191/ijcsrr/V4-i12-17, Impact Factor: 5.825

IJCSRR@ 2021

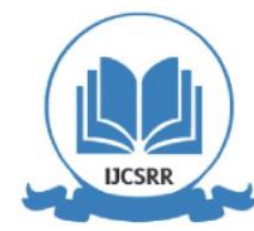

Www.ijcsrr.org

maintaining their advantages in the niche markets. The gap between the incumbent and the new entrant ultimately decrease to the point where the entrant becomes a competitive threat (Nicholas, 2020). When mainstream customers start adopting the entrants' product offerings in large volumes, disruption has occurred. The new entrant almost always wins because the incumbent is devoted to its current businesses (Nicholas, 2020).

Christensen et al. (2018) made two important observations regarding disruptive innovations. "Firstly, disruptive innovations originate in low-end or new-markets" (Christensen et al., 2018). According to theory, the low-end markets exist because incumbents typically focus on their most lucrative and demanding customers. They provide them with ever-improving products and services while overlooking the not-too demanding and less lucrative customers. In fact, incumbents' offerings often exceed the performance expectations of the latter

(Christensen et al., 2018). This provides an opportunity for disrupters who had initially focused on meeting the needs of these low-end customers with a sufficiently good product. In the case of new-markets, disrupters create a market where none existed. That is, they look for a chance to convert non-consumers into consumers. Secondly, disruptive innovations do not appeal to mainstream customers until quality matches up to their standards (Christensen et al., 2018). In the beginning, disruptive innovations are considered to be substandard by most of the incumbent's customers. They wait until there is an improvement in product quality before deciding to adopt the new product and readily accept its lower price. This explains how disruption drives prices down in a market (Christensen et al., 2018).

\section{The meaning of creative destruction}

Having considered some of the influential ideas on creative destruction, we now review some definitions of the term "creative destruction." Definitions of creative destruction abound amongst various researchers on creative destruction. Schumpeter (1942) described creative destruction as being "an evolutionary process within capitalism" that "transforms the economic structure from within, continually destroying the old one, continually creating the novel one". Grimm and Smith (1997) describes the process of creative destruction as follows: "An advantage is created and destroyed. Eventually every advantage will be eroded as realisation of profits invites imitation. Firms that attempt to maintain the status quo are doomed." Smith et al. (2002) define creative destruction as " the inevitable and eventual market decline of leading firms through the process of competitive action and reaction."

\section{The pros and cons of creative destruction}

As is implied by the word "destruction", creative destruction poses several challenges due to the temporary hardships that it may create (Hayter, 2017). According to Hayter (2017), the process of creative destruction predictably results in "losers" and "winners." Creative destruction, as a recurring wave, can constantly destroy "old order" and create "new order" (Schumpeter, 1942). Companies that are dedicated to the "old ways of doing things" are bound to lose out because creative destruction normally results in eradication of countless jobs and the destruction of whole industries (Hayter, 2017). Companies that fail to immediately manage with new improved technologies and skills of doing business are likely to suffer severe setbacks. Businesses that fail to take advantage of available innovations are "destroyed" by the "creative disruption" of the new businesses (Christensen, 1997). Schumpeter (1939) posits that "unemployment is the friction that occurs in the process of creative destruction, when production factors are reallocated from contracting to expanding units." Influenced by the Neo-Schumpeterian approach, much of the current literature on growth and employment conforms to Schumpeter's views on unemployment. (Aghion \& Howitt, 1994; 1998; Cabalerro \& Hammour, 1994; 1996).

However, when there is a continual development of new ideas, innovations and creativity, creative destruction has the potential of generating opportunities for the more creative and productive companies (Schumpeter, 1939; Hagedoorn, 1996). Schumpeter (1939) argues that "cyclical unemployment is technological unemployment and is ephemeral." He further argues that "technological unemployment might, nevertheless, be ever present, but, as in the case of profits, the source of technological unemployment in the industrial organism tends to exhaust itself, while new ones emerge periodically." (Schumpeter, 1939) Entrepreneurs and employees in new technologies will inevitably highlight new profit opportunities. The criticism that creative destruction has a destructive tendency is therefore only valid in the short-term as a result of the crisis that is seen when people lose their jobs. Job losses have a countervailing effect that triggers a zeal and commitment in people with an entrepreneurial mindset. In the long run, creative destruction makes a positive contribution to the transformation of people's living standards through the creation of new job opportunities and business ideas (Hayter, 2017). For instance, high levels of unemployment in Zambia have seen a lot of school leavers and entrepreneurs exploiting business opportunities that have opened up in the mobile money markets. Research shows that 


\section{International Journal of Current Science Research and Review}

ISSN: 2581-8341

Volume 04 Issue 12 December 2021

DOI: 10.47191/ijcsrr/V4-i12-17, Impact Factor: 5.825

IJCSRR@ 2021

Www.ijcsrr.org

the number of registered mobile money agent outlets doubled from 67,747 to 141,396 (between December 2018 and December 2019) and the number of active agents (on a 30-day basis) reached 90,166 in December 2019. (UNCDF, 2020)

\section{Global perspectives on creative destruction}

Empirical evidence appears to support the view that the process of creative destruction is one of major causes of business failure amongst some otherwise well- managed companies (Christensen, 1997; Hayter, 2017). Few companies are able to survive the forces of creative destruction. Research has revealed, for instance, that every year a number of companies drop off the S\&P 500 list and are replaced by others (Anthony, Viguerie, \& Schwartz, 2018). According to Anthony et al. (2018), "the reduction in the lifespans of companies on the S\&P 500 list is driven to some extent by a complex combination of technology shifts and economic shocks". Companies often miss the chance to either adjust or to take advantage of these changes (Innosight, 2012). Innosight (2012) contends that "companies continue to apply current business models to new markets, they are slow in responding to disruptive competitors in less lucrative segments, or they simply fail to adequately envision and invest in new growth areas".

Christensen (1997) has also highlighted incidences involving companies that have yielded to the forces of creative destruction. Christensen (1997) posits that a sizable number of well-managed companies have faded into obscurity despite these companies having "their competitive antannae up, listening astitutely to their customers and even investing aggressively in new technologies." A characteristic example of such companies include Sears Roebuck, IBM and Netfllix (Hayter, 2017). Sears inadvertently missed the emergence of discount retailing and home centres, and lost market dominance (Christensen, 1997). This pattern of creative destruction continues to be played out in many other industries. Take the computer industry, for example. IBM used to be a dominant player in the mainframe market. However, the dawn of minicomputers, that were technologically simpler and much more superior to mainframes, ended the market dominance of IBM (Foster, 1986). Xerox was also a dominant player in the market for plain paper photocopiers used in large, high-volume copying centers. Just like IBM, Xerox missed out on the enormous growth and profit opportunities in the market for small desktop office copiers (Christensen, 1997). The world also witnessed attacks on long-time market leaders, such as the attack of Apple on IBM, or Netflix on Blockbuster (Anthony et al., 2018). In Zambia, a notable industry that could be said to have been negatively impacted by innovative disruption has been the postal services industry. Swift Cash, a money transfer service offered by the Zambia Postal Services, has almost been obliterated by the mobile money market.

\section{METHODOLOGY AND DATA}

\section{Introduction}

This section presents the research methodology that was applied in this study. The section seeks to outline the research paradigm, approach and design. It also discusses data collection methods and the models used in testing the research hypotheses.

\section{Research paradigm and approach}

The study, which was largely positivist in nature, employed quantitative research in a cross-sectional study (Saunders, 2009). A crosssectional study is "a research study for which data are gathered just once (stretched though it may be over a period of days, weeks, or months) to answer the research question (Sekeran, 2003)." The research study employed a deductive approach. The reason for using a deductive approach was because the aim of the study was to arrive at "a reasoned conclusion by logical generalization of a known fact" (Sekeran, 2003).

\section{Research design}

The researchers employed a non-experimental, hypothesis- testing research study (Kothari, 2004). This research design was considered appropriate because the purpose of research was to test the research hypothesis, and did not involve the manipulation of the independent variable (Sekeran, 2003).

\section{Data and sources}

Secondary data for this study were obtained from an online survey report authored by the United Nations Capital Development Fund (UNCDF) in collaboration with the Zambia's central bank, the Bank of Zambia (BoZ). The online survey report, which contained the results from the UNCDF Annual Provider Survey 2019 Zambia, was administered to digital financial services (DFS) providers in Zambia. Participants in the survey included banks, microfinance institutions (MFIs), mobile network operators (MNOs) and thirdparty providers. There was a total of 21 providers in Zambia, and all of them were invited to participate in the survey. Of those invited, 


\section{International Journal of Current Science Research and Review}

ISSN: 2581-8341

Volume 04 Issue 12 December 2021

DOI: 10.47191/ijcsrr/V4-i12-17, Impact Factor: 5.825

IJCSRR@ 2021

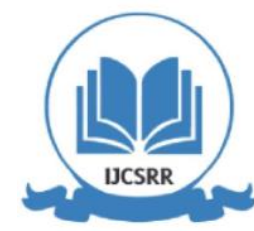

www.ijesrr.org

19 providers responded to the 2020 survey (representing a 95 percent response rate). The providers that participated in the survey included 11 banks, 3 MNOs, 4 third-party operators (including one new entry) and 1 MFI. Survey data were self-reported and were validated with the support of the BoZ.

Table 2.1. Digital Financial Services Providers in Zambia (Source: United Nations Capital Development Fund, 2020)

\begin{tabular}{|l|l|}
\hline Description of participants & Number of respondents \\
\hline Banks & 11 \\
\hline MFIs & 1 \\
\hline MNOs & 3 \\
\hline Third-party providers & 4 \\
\hline Total & 19 \\
\hline
\end{tabular}

\section{Data Processing and Analysis}

To establish the trend in secondary data and to determine whether there was a linear relationship between usage of mobile money services (considered as an independent variable, $\mathrm{x}$ ) and usage of digital banking services (considered as a dependent variable, $\mathrm{y}$ ), the study used time series trend analysis and simple linear regression analysis (Stephens, 1988). The data was processed using MS Excel package. The resulting estimated regression equation and the coefficient of correlation and determination indicated the direction and the strength of the relationship between the predictor/independent and dependent variables (Saunders, 2009). The correlation coefficient (denoted by " $r$ ") can take on any value between -1 and +1 . A value of +1 would represent a perfect positive correlation whereas a value of -, would represent a perfect negative correlation. Correlation coefficients between -1 and +1 would indicate a weaker positive and negative correlation, and a value of 0 would mean the variables are perfectly independent. Furthermore, in order to test the null hypothesis; that $\mathrm{p}=0$ (that states that there is no correlation) versus the alternative $\mathrm{p}<0$ (that states that an inverse correlation exists), a t- test was carried out at a level of significance, $a=0.05$ (that is, at a confidence level of 95 percent). The test statistic was determined by noting that the degree of freedom, $\mathrm{df}=\mathrm{n}-2$. (Stephens, 1988)

\section{Reliability, validity and generalizability of research findings}

The source of data used in this research was from the UNCDF Annual Provider Survey 2019 Zambia (UNCDF, 2020). The survey data were validated with the support of the BoZ. Prior to the data being validated by BoZ, individual data validation sessions were held with each DFS provider (UNCDF, 2020). Furthermore, the qualitative insights from the validation sessions assisted in strengthening the results reported from the quantitative data. It follows therefore that the data used in this research study had a preestablished degree of validity and reliability (Otiono, 2021). In terms of generalizability (also referred to as external validity), the results of the study were considered to be generalizable owing to the high response rate of 95 percent recorded from the UNCDF Annual Provider Survey (Saunders, 2009). It is anticipated that the research findings can be generalized within developing countries sharing the same socio-economic background to Zambia.

\section{Ethical and access Issues}

In terms of accessibility, this study utilized data from UNCDF which was readily accessible online. The data being readily available online meant that no prior ethical approval was required in order to access the data. The researchers were therefore relieved from the burden of applying for ethical approval. The use of secondary data is a highly ethical practice because it maximizes the value of any (public) investment in data collection. It also reduces the burden on respondents and ensures replicability of study findings and therefore, greater transparency of research procedures and integrity of research work

\section{Limitations of the study}

The researchers' ability to adequately address the research question was constrained by the use of secondary data. The secondary data that was used in this study was originally collected for a different purpose by UNCDF and was not available in the precise format required for the research. In addition, the researchers were not able to access all the data required in the research due to the Covid 19 restrictions and protocols that were in place. 


\section{International Journal of Current Science Research and Review}

ISSN: 2581-8341

Volume 04 Issue 12 December 2021

DOI: 10.47191/ijesrr/V4-i12-17, Impact Factor: 5.825

IJCSRR@ 2021

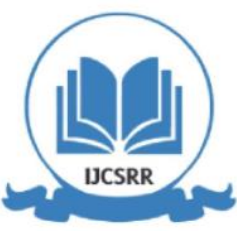

www.ijesrr.org

\section{FINDINGS AND DISCUSSION}

\section{Introduction}

This section discusses the results of times series trends and regression analyses using MS Excel. It also interprets results in the context of the research question, objectives and hypotheses. The key results, in form of tables and graphs, are contained in this section.

\section{Descriptive statistics}

For the purpose of this research study, only data for banks and MNOs were extracted for further processing and analysis. The data of interest for the purpose of this research study, which represented usage of mobile money services and digital banking services, was the reported results on the numbers of registered and active customer accounts (90 day) covering the period from 2016 to 2019 . An extract of this data is given in the table 3.1 below, and shows the market share for banks, MNOs and other DFS providers.

\section{Market share}

Table: 3.1 Market Share Active (90) Dfs Accounts (Source: Extract From United Nations Capital Development Fund Report, 2020)

\begin{tabular}{|l|l|l|l|l|}
\hline Year & MNOs & Banks & Others & Total \\
\hline & $\%$ & $\%$ & $\%$ & $\%$ \\
\hline 2016 & 60,15 & 39,50 & 0,35 & 100,00 \\
\hline 2017 & 74,87 & 23,13 & 2,00 & 100,00 \\
\hline 2018 & 87,89 & 10,68 & 1,43 & 100,00 \\
\hline 2019 & 89,14 & 10,64 & 0,22 & 100,00 \\
\hline
\end{tabular}

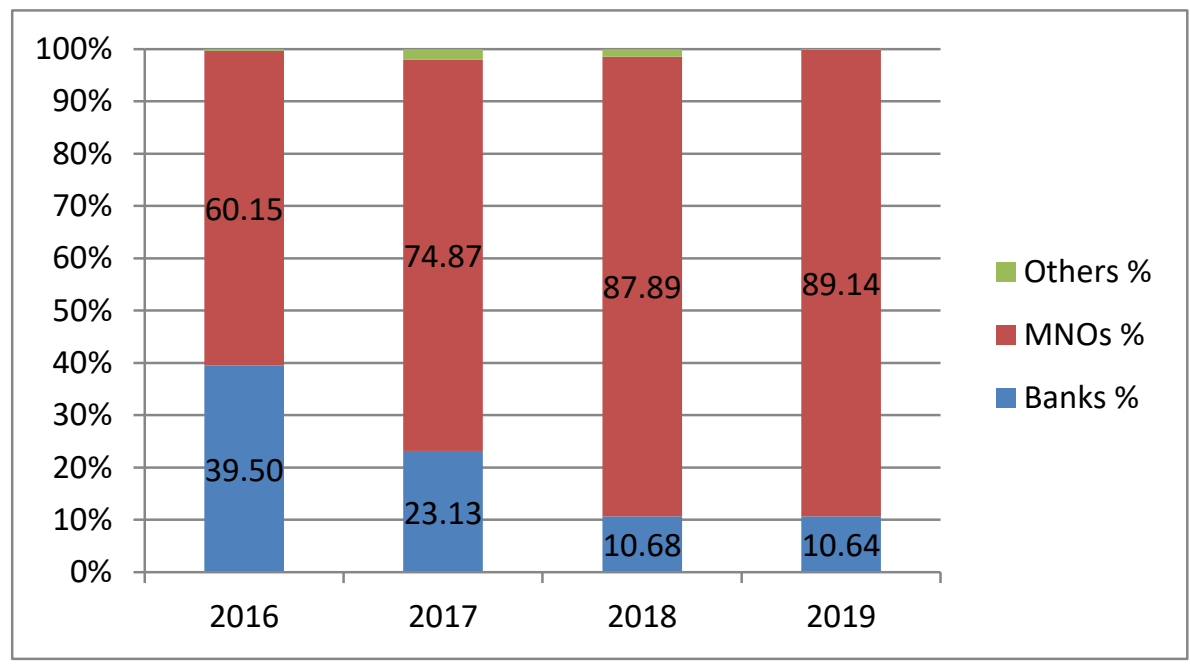

Figure: 3.1 Market Share Active (90) Dfs Accounts (Compiled By Authors From Ms Excel)

From Table 3.1 and Figure 3.1, the market share for MNOs increased from 60 percent in 2016 to 89 percent in 2019. During the same period, the market share for banks declined from 39 percent in 2016 to 10 percent in 2019.

\section{Number of registered and active customer accounts}

Table 3.2 (below), shows the number of registered and active customer accounts since 2016 for each category of digital financial services provider. The totals column shows total number of registered and active customers for digital financial services (UNCDF, 2020). The columns for "banks, MNOs and others" were arrived at based on the market share enjoyed by each category the digital financial services provider as given in Table 3.1. 


\section{International Journal of Current Science Research and Review}

ISSN: 2581-8341

Volume 04 Issue 12 December 2021

DOI: 10.47191/ijesrr/V4-i12-17, Impact Factor: 5.825

IJCSRR@ 2021

Www.ijesrr.org

Table: 3.2. Number of Registered \& Active Customer Accounts Since 2016 (Source: Extract From United Nations Capital Development Fund Report, 2020)

\begin{tabular}{|l|r|r|r|l|}
\hline Year & \multicolumn{2}{|l|}{ MNOs } & Banks & Totals \\
\hline 2016 & 781950 & 513500 & 4550 & 1300000 \\
\hline 2017 & 1722010 & 531990 & 46000 & 2300000 \\
\hline 2018 & 3819575 & 464138 & 62145 & 4345858 \\
\hline 2019 & 5814066 & 693983 & 14350 & 6522399 \\
\hline
\end{tabular}

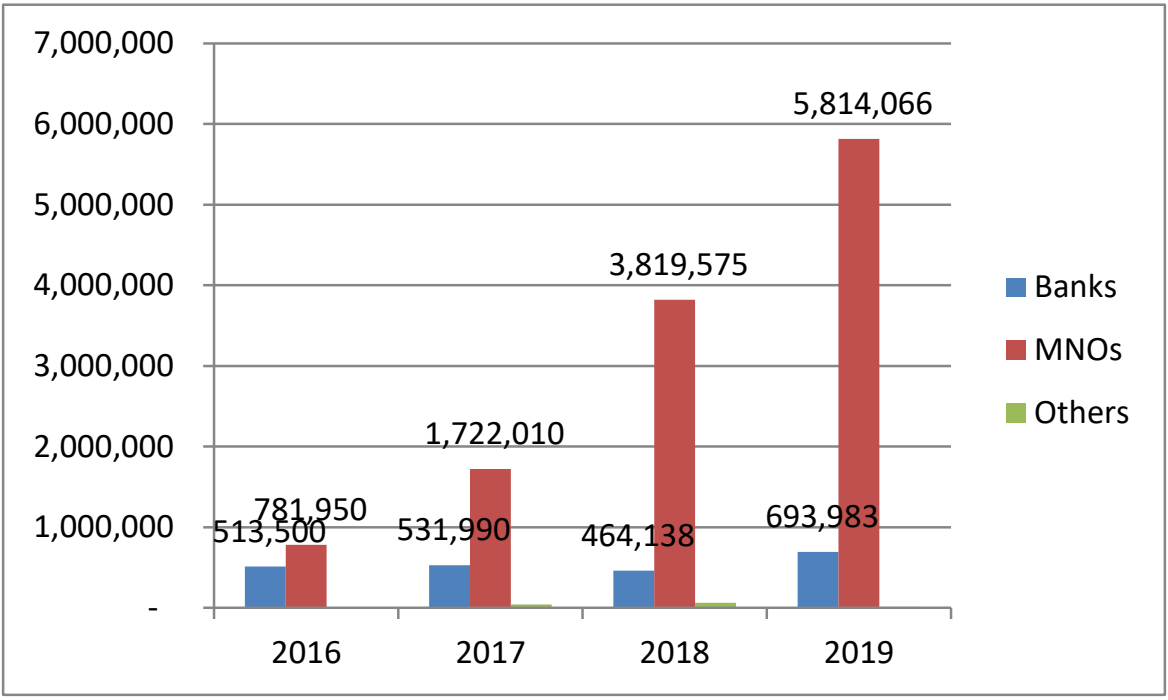

Figure 3.2. Number of Registered \& Active Customer Accounts since 2016(Compiled By Authors from Ms Excel)

To be considered as active, a digital financial services (DFS) account must have been active for a 90-day period (UNCDF, 2020).From Table 3.2 and Figure 3.2, the number of registered and active customer accounts for MNOs increased from 782 , 000 in 2016 to 5.8 million in 2019. During the same period, the number of registered and active customers for banks increased from 514,000 to 694, 000 in 2019.

Trends in market share and number of registered and active customer accounts

Figure 4.1 shows an upward trend in the market share for MNOs between 2016 and 2019. During same period, Figure 4.1 shows a downward trend in the market share for banks

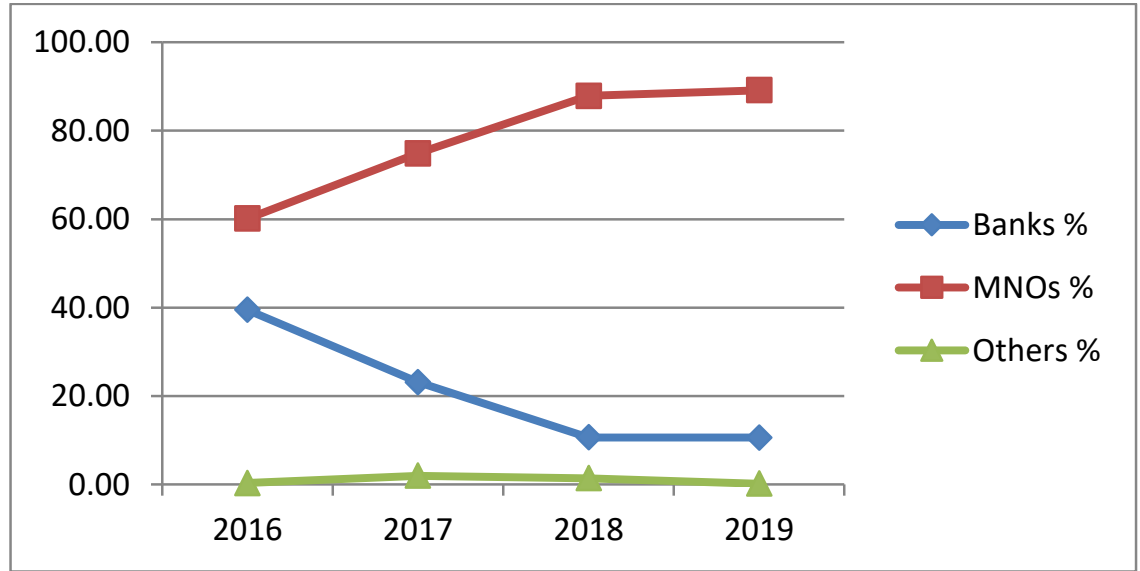

Figure 4.1 Trends In Market Share Active (90) DFS Accounts (Compiled By Authors from MS Excel) 


\section{International Journal of Current Science Research and Review}

ISSN: 2581-8341

Volume 04 Issue 12 December 2021

DOI: 10.47191/ijcsrr/V4-i12-17, Impact Factor: 5.825

IJCSRR@ 2021

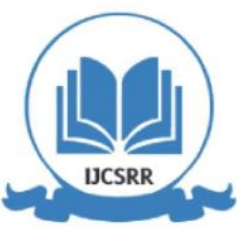

www.ijesrr.org

Figure 4.2 shows an upward trend in the numbers of registered and active customer accounts for MNOs between 2016 and 2019. During the same period of 2016 to 2019, Figure 4.2 did not show any clear movement up or down in the numbers of registered and active customer accounts for banks. The trend was therefore considered to be static or a level one.

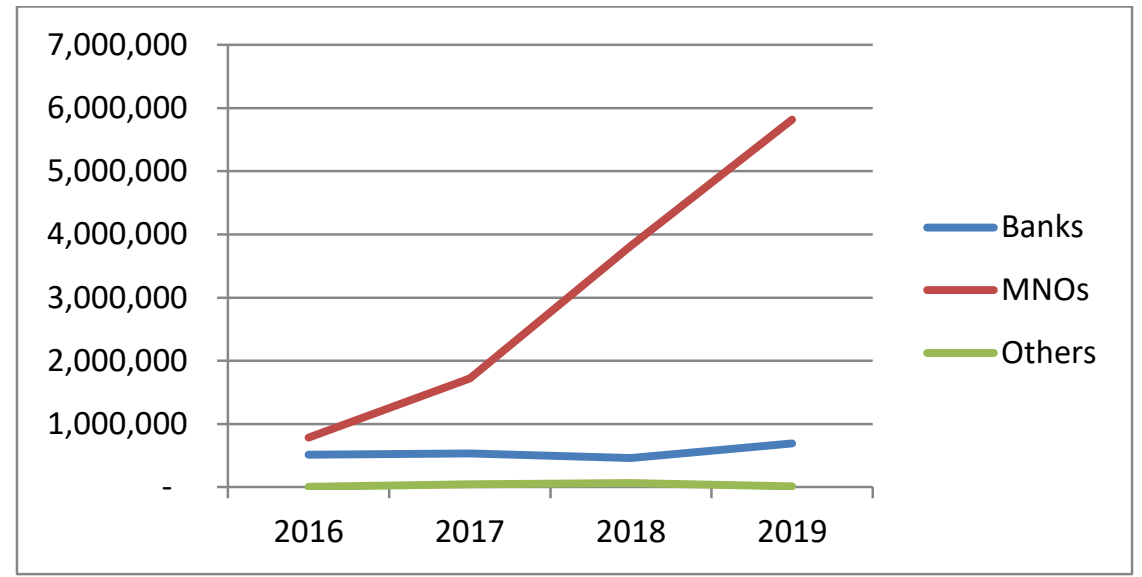

Figure 4.2. Trends in Numbers of Registered \& Active Customer Accounts since 2016(Compiled By Authors from MS Excel)

\section{Results from MS Excel}

Table 4.1: Compiled By Authors from MS Excel

\begin{tabular}{|l|l|l|}
\hline Statistic & Value & \\
\hline Pearson Moment Correlation Coefficient (PMCC), $\mathrm{r}$ & 0.653561 & \\
\hline Coefficient of determination, $\mathrm{r}^{2}$ & 0.427142 & \\
\hline$\beta$ o $(\mathrm{y}$-intercept) & 462,979 & \\
\hline Constant (slope of the line) & 0.029 & \\
\hline Level of significance, $\mathrm{a}$ & 0.05 & \\
\hline Test statistic, $\mathrm{t}^{*} \cdot$ & 2.1151 & \\
\hline $\mathrm{t}$-value for a left-tail area equal to 0.05 & -1.943 & \\
\hline Degree of freedom, $\mathrm{df}=\mathrm{n}-2$, where $\mathrm{n}=8$ & 6 & \\
\hline
\end{tabular}

\section{The Least Squares Line}

Also known as the line of best fit or prediction line, the equation of the least squares line for the pairs of collected data was represented by the following formula (Stephens, 1988).

$$
\mathrm{y}=\beta_{\mathrm{o}}+\beta_{1} \mathrm{x}
$$

The linear regression model assumed that some dependent or response variable, represented by y (representing the usage of digital banking services), was related to an independent variable, represented by x. (representing the usage of mobile money services). The intercept, $\beta \mathrm{o}$ and the slope, $\beta_{\mathrm{l}}$, were unknown parameters and were estimated from the pairs of collected data given in Table 4.1. The $y$ - intercept, $\beta o=462,979$ and the slope of the line, $\beta_{1}=0.029$ (a positive value meant that the line was upward sloping). In a simple linear regression model, if $\mathrm{x}$ and $\mathrm{y}$ are linearly related, $\beta_{1} \neq 0$, that is, the gradient is not equal to zero. The equation of the line was:

$$
y=462,979+0.029 x
$$

\section{The Scatter plot}

The scatter plot derived from available pairs of data in Table 3.2, revealed a partial positive correlation. Assuming that there was a linear relationship between the two variables, results from regression analysis produced the equation of a straight line, $\mathrm{y}=462,979$ $+0.029 \mathrm{x}$, which was considered a good fit for available plotted data. 


\section{International Journal of Current Science Research and Review}

ISSN: 2581-8341

Volume 04 Issue 12 December 2021

DOI: 10.47191/ijesrr/V4-i12-17, Impact Factor: 5.825

IJCSRR@ 2021

www.ijesrr.org

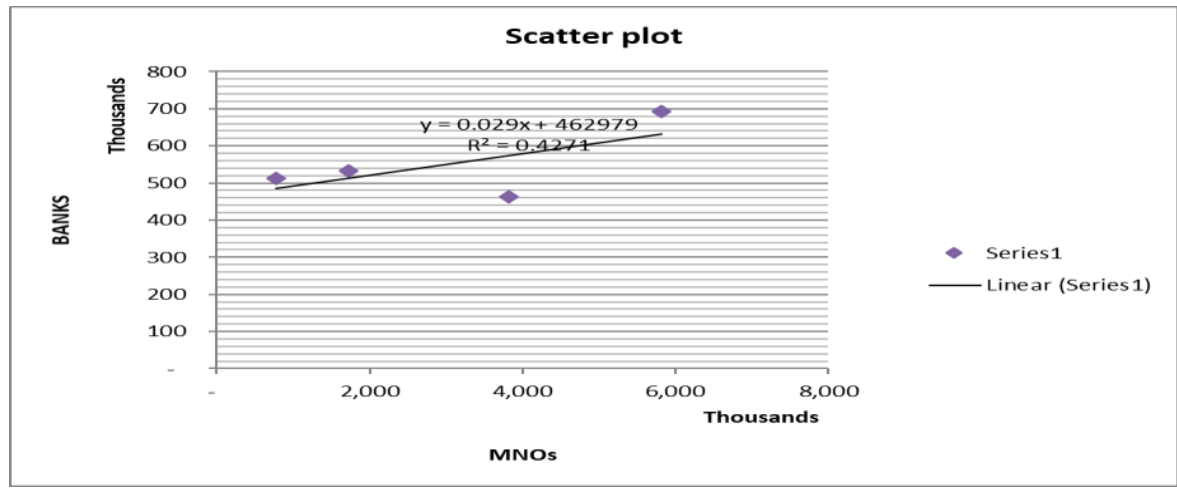

Figure 4.3: Scatter Plot Showing Relationship between the Predictor/Independent \& Dependent Variables (Compiled By Authors from MS Excel)

\section{Pearson Moment Correlation Coefficient (PMCC) and Coefficient of Determination, $r^{2}$}

The degree of correlation, "r", between $\mathrm{x}$ (representing number of registered and active customers for mobile money services) and y (representing numbers of registered and active customers for digital banking services) was 0.653561 . The value, " $\mathrm{r}$ " fell between 0 and +1 . This meant that there was a partial positive correlation between the usage of mobile money services and the usage of digital banking services.

The coefficient of determination, $\mathrm{r}^{2}$, was 0.427142 , which indicated a weak linear relationship. Expressed as a percentage, this implied that only 42.7 percent of observed variations in the usage of digital banking services could be explained by the fitted least square line, which left 57.3 percent to be explained by other factors. This did not necessarily mean that 42.7 percent of observed variations in the usage of digital banking services were caused by variations in the usage of mobile money services (ACCA, 2001).

\section{Test of research propositions (t-test)}

The study was interested in testing the null hypothesis, $\mathrm{p}=0$, versus the alternative hypothesis, $\mathrm{p}<0$.

Rejection rule: Reject $\mathrm{H}_{\mathrm{o}}$ if $\mathrm{t}^{*}<-\mathrm{ta}$, where ta was based on a t-distribution, with degree of freedom, $\mathrm{n}-2$, at level of significance, 0.05 . The computed value of the test statistic, $t^{*}$, in Table 4.1 was: 2.1151 ; and was given by the formula:

$$
\begin{gathered}
\mathrm{t}^{*}=\mathrm{r} \sqrt{ } \mathrm{n}-2 \\
1-\mathrm{r}^{2}
\end{gathered}
$$

The $\mathrm{t}$-value for a left tail area equal to 0.05 was found to be ta $=1.943$. Since this was a lower tail test, the critical value was -1.943 . Since, $2.1151>-1.943$, the null was accepted. It was therefore concluded at $95 \%$ confidence level that there was no correlation between the increased usage of mobile money services and the usage of digital banking services in Zambia.

\section{CONCLUSION}

On the basis of the findings above, not only were the research objectives realized, but the research problem and question were addressed. In summary, the study concluded as follows.

- There was an upward trend in the usage of mobile money services during the period under consideration. During the same period, the trend analysis results depicting usage of digital banking services were considered to be static.

- There was a partial positive correlation between the usage of mobile money services and the usage of digital banking services. However, the linear relationship between the two variables was considered to be weak.

- The study failed to reject the null hypothesis. The researchers therefore concluded that there was no correlation between the increased usage of mobile money services and the usage of digital banking services.

- The study expounded research results in terms of Schumpeter, Christensen and Foster's ideas on disruptive innovation that may have far-reaching implications on the way the process of creative destruction unfolds in particular markets. For instance, Christensen suggests that disruptive innovation tends to originate in "low-end" or "new markets", which the incumbent firms (banks) may have neglected. Evidently, this implies that entrants (MNOs) may have initially targeted these overlooked and 


\section{International Journal of Current Science Research and Review}

ISSN: 2581-8341

Volume 04 Issue 12 December 2021

DOI: 10.47191/ijcsrr/V4-i12-17, Impact Factor: 5.825

IJCSRR@ 2021

Www.ijcsrr.org

neglected segments in the financial services market. Therefore, the increased usage of mobile money services may not reveal a correlation with digital banking services usage in the initial stages of introducing mobile money services on the market. However, as the process unfolds, theory predicts that incumbents' (banks) mainstream customers may eventually convert to the entrants' (MNOs) product offerings, whose quality would have improved. Schumpeter argues that if a business does not take advantage of available innovations on the market, it will eventually be destroyed by the creative disruption of the new businesses. Eventually, as suggested by Foster, incumbents (banks) may ultimately lose control of the market, through the process of disruption from below. The researchers therefore reasoned that the fact that the assumed relationship between the usage of mobile money services and usage of digital banking services did not exist (during the period under consideration), could not necessarily be used to completely discount the process of creative destruction and its effect in financial services sector in Zambia.

\section{AREA FOR FURTHER RESEARCH}

Having established that the assumed relationship between the usage of mobile money services and the usage of digital banking services does not exist, the researchers recommended that further research be conducted in this area that should involve more pairs of data. The larger the number of pairs of data collected, the more likely it is to establish observable links between the independent and dependent variables.

\section{REFERENCES}

1. ACCA. (2001). Paper 1.2 Financial Information for Management December 2001 and June 2002. London: BPP Publishing Limited Aldine House, Aldine Place.

2. Aghion, P., \& Howitt, P. (1994). Growth \& Unemployment. Review of Economic Studies, 477 - 494.

3. Aghion, P., \& Howitt, P. (1998). Endogenous Growth Theory. Cambridge (Mass): MIT Press.

4. Anthony, S., Viguerie, S., \& Schwartz, E. \&. (2018). Innosight 2018 - Corporate Longevity Forecast: Creative Destruction is Accelerating. Innosight.

5. Bank of Zambia. (2020). State of Digital Financial Services Market in Zmbia 2019. Bank of Zambia. Lusaka: Bank of Zambia and UNCDF.

6. Cabalerro, R., \& Hammour, M. (1994). The Cleansing Effects of Recessions. American Economic Review, 1350 - 1368.

7. Caballero, R., \& Hammour, M. (1996). On the Timing \& Effificiency of Creative Destruction. Quarterly Journal of Economics, 805-852.

8. Chileshe, C. (2019, November 24). A Review of Financial Inclusion in Zambia. Retrieved April 13, 2021, from Reserachgate: https://www.researchgate.net/publication/337482368

9. Christensen, C. M. (1997). The Innovators Dilemma - When New Technologies Cause Great Firms to Fail. Boston, Massachusetts, USA: Harvard Business School Press.

10. Christensen, C., Raynor, M., \& McDonald, R. (2018, December). Disruptive Innovation - What is Disruptive Innovation. Retrieved April 05, 2021, from Harvard Business Review: https://hbr.org/2015/12/what-is-disruptive innovation

11. de Bruijn, M., Butter, I., \& Fall, A. (2017). An Ethnographic Study on Mobile Money Attitudes, Perceptions \& Usages in Cameroon, Congo DRC, Senegal \& Zambia.

12. FinScope. (2020). FinScope 2020 Top line Findings. Lusaka.

13. Foster, R. N. (1986). Innovation: The Attackers Advantage. London: Macmillan.

14. Foster, R., \& Kaplan, S. (2001). Creative Destruction. United States: Mckinsey \& Company, Inc.

15. Grebel, T., Pyka, A., \& Hanusch, H. (2001). An Evolutionary Approach to the Theory of Entrepreneurship. ECONSTOR, 2 .

16. Grimm, C. \&. (1997). Strategy in action: Industry Rivalry and Coordination. Cincinnati: South-Western College Publishin.

17. Hagedoorn, J. (1996). Innovation \& Entrepreneurship- Schumpeter Revisited. Oxford University Press.

18. Hagedoorn, J. (1996). Innovation and Entrpreneurship: Schumpeter Revisited. Industrial and Corporate Change, 5(3), 1 14.

19. Hayter, G. (2017). Innovation \& Business Performance. New Malden, Surrey, UK: Association of Business Executives. 


\section{International Journal of Current Science Research and Review}

ISSN: 2581-8341

Volume 04 Issue 12 December 2021

DOI: 10.47191/ijesrr/V4-i12-17, Impact Factor: 5.825

IJCSRR@ 2021

www.ijesrr.org

20. Innosight. (2012). Creative Destruction Whips through Corporate America - To survive \& thrive business leaders must create, operate \& trade without losing control. 92 Hayden Avenue, Lexington, MA: Innosight.

21. Kothari, C. (2004). Reserach Methodology - Methods \& Techniques (Second Revised Edition ed.). Nee Delhi: New Age International Publisher.

22. Lin, C. Y.-Y.-C. (2007). Does Innovation Lead to Performance?An Empirical Study of SME's in Taiwan. Management Reserach News, 30(2), 113-132.

23. Nicholas, T. (2020, July). How History Shaped the Innovators Dilemma. Harvard Business School.

24. Nord, W. a. (1987). Implementing Routine and Radical Innovations. Lexington, MA: Lexington Books.

25. PwC Zambia. (2019). 2018 Zambia Banking and Non-banking Industry Survey. Lusaka: PwC Zambia.

26. Saunders, M. L. (2009). Research methods for business students (5th ed.). Edinburgh Gate, Harlow Essex CM20 2JE, England: Pearson Education.

27. Schumpeter, J. (1934). The Theory of Economic Development. London: Oxford University Press.

28. Schumpeter, J. (1939). Business Cycles. Philadelphia: Porcupine Press.

29. Schumpeter, J. (1942). Capitalism, Socialism, and Democracy. New York: Harper and Bros.

30. Sekeran, U. (2003). Research Methods for Business - A Skill Building Approach (Fourth Edition ed.). Illinois, US: John Wiley \& Sons, Inc.

31. Smith, K. F. (2002). Competitive Dynamics Reserach: Critique and Future Direction. In J. H. M. Hitt, Handbook of Strategic Management (pp. 315 - 361). UK: Blackwell.

32. Stephens, L. (1988). Beginning Statistics. New York: Schaums.

33. Stolper, W. (1994). Joseph Schumpeter - The Public Life of a Private Man. Princeton, NJ: Princeton University Press.

34. Suri, J. A. (2021). "Mobile Money". VoxDevLit, 2(1).

35. United Nations Capital Development Fund. (2020). State of Digital Financial Services Market in Zmbia 2019. Bank of Zambia. Lusaka: Bank of Zambia and UNCDF.

36. Urabe, K. C. (1988). Innovation and Management: International Comparisons. Berlin: Walter de Gruvter \& Co.

37. West, M. a. (1990). Innovation and Creativity at Work. Chichester: John Wiley \& Sons.

38. World Bank. (2021). Zambia - Overview. www.worldbank.org/en/country/Zambia/overview; Accessed 16/03/2021.

Cite this Article: Billy Kaombe, Francis Mukosa, Dr. Windu Matoka, Rabbie Mukuma (2021). Creative Destruction - An Inevitable Reality for the Financial Services Sector in Zambia?. International Journal of Current Science Research and Review, 4(12), 1729-1742 